\title{
SEEDLINGS OF TREE SPECIES PRODUCED IN SUBSTRATES BASED ON ORGANIC COMPOSTS
}

\author{
Oclizio Medeiros das Chagas Silva ${ }^{*}$, Marileydy Martínez Hernández², Rodolfo Soares de Almeida ${ }^{3}$, Ramon
} Pittizer Moreira ${ }^{4}$, Paulo Sérgio dos Santos Leles ${ }^{5}$, Lucas Amaral de Melo ${ }^{6}$

1*Federal Rural University of Rio de Janeiro, PhD student by the Postgraduate Program in Environmental and Forest Sciences, Seropédica, Rio de Janeiro, Brazil - omflorestal@ hotmail.com

${ }^{2}$ Federal University of Lavras, PhD student by the Postgraduate Program in Forest Engineering, Lavras, Minas Gerais, Brazil deydy_17@hotmail.com

${ }^{3}$ Federal University of Lavras, PhD student by the Postgraduate Program in Forest Engineering, Lavras, Minas Gerais, Brazil rodoxalmeida1991@gmail.com

${ }^{4}$ Federal Rural University of Rio de Janeiro, Master by the Postgraduate Program in Environmental and Forest Sciences, Seropédica, Rio de Janeiro, Brazil - ramon_pittizer@hotmail.com

${ }^{5}$ Federal Rural University of Rio de Janeiro, Professor in the Department of Silviculture, Seropédica, Rio de Janeiro, Brazil psantosleles@gmail.com

${ }^{6}$ Federal Rural University of Rio de Janeiro, Professor in the Department of Silviculture, Lavras, Minas Gerais, Brazil lucas.amaral@dcf.ufla.br

Received for publication: 05/09/2019 - Accepted for publication: 24/05/2020

\begin{abstract}
Resumo
Mudas de espécies arbóreas produzidas em substratos à base de compostos orgânicos. A qualidade da muda produzida está diretamente relacionada com a composição do substrato, sendo essencial a seleção de constituintes que apresentem características adequadas. Objetivou-se avaliar a produção de mudas de Eucalyptus urophylla, Peltophorum dubium e Eremanthus erythropappus e também relacionar as características físicas e químicas dos substratos formulados com a qualidade das mudas formadas. Para cada espécie foi conduzido um experimento, instalado em delineamento inteiramente casualizado (DIC), constituídos por cinco tratamentos, cinco repetições, e parcelas compostas por 20 mudas. Para avaliação da qualidade das mudas, foram mensuradas as variáveis biométricas e como análises qualitativas, foram avaliadas a facilidade de retirada das mudas do tubete (ERT) e a agregação das raízes ao substrato (AGGR). As mudas produzidas nos substratos formulados com constituintes alternativos apresentaram valores superiores quando comparados às mudas produzidas com o substrato comercial, para a maioria das variáveis analisadas. A casca de café pode ser aplicada na produção de mudas de $P$. dubium e de E. urophylla. Já para a formação de mudas de E. erythropappus, não se recomenda nenhuma das formulações testadas.

Palavras-chave: casca de café, constituinte alternativo, parâmetros morfológicos, qualidade de mudas florestais.
\end{abstract}

Abstract
The quality of the seedling produced is directly related to substrate composition, so it is essential to select constituents with adequate characteristics. The objective of this study was to evaluate Eucalyptus urophylla, Peltophorum dubium and Eremanthus erythropappus seedlings and to relate the physical and chemical characteristics of the formulated substrates to their quality. For each species, an experiment was carried out in a completely randomized design (CRD), consisting of five treatments, five replicates, and plots composed of 20 seedlings. In order to evaluate the quality of the seedlings, the biometric variables were measured and, as a qualitative analysis, the ease to remove the seedlings from the tubes (ERT) and root aggregation to the substrate (AGGR) were evaluated. Seedlings produced in the substrates formulated with alternative constituents showed higher values when compared to seedlings produced with commercial substrate, for most of the analyzed variables. Coffee husk can be applied in the production of seedlings of $P$. dubium and E. urophylla. For the formation of E. erythropappus seedlings, none of the formulations tested are recommended.

Keywords: coffee husk, renewable constituents, morphological parameters, quality of forest seedlings.

\section{INTRODUCTION}

For the formation of forest stands, it is necessary to produce seedlings with quality, which depends on several factors, especially the constituents of the substrate and their proportions. Initially, the main constituent used in the formulation of substrates was the soil itself, combined with bovine manure, mainly for the production of seedlings in plastic bags (TRAZZI et al., 2012). With the advancement of technology in seedling production and the greater use of tubes, other types of materials considered waste emerged, which began to be widely used (CALDEIRA et al., 2013; KRATZ et al., 2016).

In the selection of substrate components, which meet the requirements for the production of quality seedlings, some characteristics must be observed. The substrate should be low cost, easily accessible, homogeneous, not degrade or shrink significantly with use, and be free of pathogens (KRATZ et al., 2016). Physical characteristics such as density, porosity, water holding capacity, and chemical characteristics, such as electrical conductivity, $\mathrm{pH}$, among others, should also be considered (DORNELLES et al., 2014).

FLORESTA, Curitiba, PR, v. 51, n. 2, p. 371-380, abril/jun 2021.

Silva, O. M. C. et.al.

ISSN eletrônico 1982-4688

DOI: $10.5380 /$ rf.v51 i2. 69047 
According to Delarmelina et al. (2014) and Alonso et al. (2018), substrates can consist of a single material or can be formulated using different types of materials, the latter being the most indicated, since it gathers several characteristics considered desirable in a single mixture. Among the most used constituents, vermiculite, carbonized rice husk, coconut fiber, sawdust and peat stand out.

Coconut fiber is a material that has been widely used in the formulations of substrates. The main characteristics of this material are low cost, easy handling, good water absorption capacity and it also provides adequate conditions for seed germination (DELARMELINA et al., 2014). This material has good aeration and high physical stability, ideal characteristics for a good constituent for substrate.

Bovine manure is mainly used due to its low cost and availability in several regions of Brazil, contributing to the reduction of costs in the production of seedlings. It contributes to the improvement of the physical quality of the substrate, influencing water infiltration capacity, also improving the possibility of root penetration (TRAZZI et al., 2012).

Another constituent widely used in seedling production is carbonized rice husk. This can contribute to the improvement of physical-hydraulic properties, mainly due to the increase in the porosity of the substrates.

However, the main disadvantage is related to its availability and cost of transportation outside the southern region of Brazil (KRATZ et al., 2013a), because the largest areas of rice cultivation are found in Rio Grande do Sul (CONAB, 2015).

In this context, the use of regional waste can considerably reduce the cost of the substrate (WENDLING et al., 2007; MELO et al., 2014). Lately, in coffee-producing regions, such as the southern region of Minas Gerais, coffee husks have been tested in different forms in seedling production, emerging as a good option, mainly due to the easy accessibility and reduced cost in coffee-producing regions (SILVA et al., 2020). Regarding the use of this by-product as a constituent in the formulation of substrates for the production of seedlings of tree species, there are still few studies on its effects in the literature. In this context, it is important to conduct research to evaluate whether this constituent has the potential to be used in seedling production, thus replacing the dependence on rice husk.

Another possibility is the use of a commercial substrate, as it is already ready and formulated. The disadvantage of this material is its cost, which can be high when compared to alternative materials. In addition, pine bark, one of the main constituents of this substrate, is also used for other purposes, such as burning for energy generation, which reduces the availability of this by-product (KRATZ et al., 2013a).

In view of the above, the objective was to evaluate the initial growth of seedlings of three forest species produced in different substrate formulations and also to relate the physical and chemical characteristics of the formulated substrates with their quality, assessing the possibility of replacing the constituent carbonized rice husk with carbonized coffee husk.

\section{MATERIAL AND METHODS}

The experiment was conducted in a forest nursery located in southern Minas Gerais $\left(21^{\circ} 13^{\prime} 14.033^{\prime \prime} \mathrm{S}\right.$ and $44^{\circ} 58^{\prime}$ 0.232" W), from April to November 2018. The tree species used were Eucalyptus urophylla (S. T. Blake), Peltophorum dubium (Spreng.) Taub. and Eremanthus erythropappus (DC.) MacLeish.

Four types of constituents for substrate formulation were evaluated: carbonized coffee husk, carbonized rice husk, coconut fiber and bovine manure. As a control, the commercial substrate Maxfértil was tested, composed of $85 \%$ of composted pine bark, $10 \%$ of vermiculite and $5 \%$ of carbonized husk/bark (rice and pine) and enriched with mineral fertilizer NPK 4-14-8.

For each species, an experiment was conducted, installed in a completely randomized design (CRD), consisting of five treatments, with five replicates, and the experimental unit consisted of 20 seedlings. The proportions of treatments are presented in Table 1.

Table 1. Volumetric proportions of two constituents (\%) used in the formulation of two substrates for the production of Eucalyptus urophylla, Peltophorum dubium and Eremanthus erythropappus seedlings.

Tabela 1. Proporções volumétricas dos constituintes (\%) utilizados na formulação dos substratos para a produção de mudas de Eucalyptus urophylla, Peltophorum dubium e Eremanthus erythropappus.

\begin{tabular}{cccccc}
\hline Treatments & BM & CF & CRH & CCH & CS \\
\hline T1 & 30 & 20 & 50 & - & - \\
T2 & 30 & 20 & 30 & 20 & - \\
T3 & 30 & 20 & 15 & 35 & - \\
T4 & 30 & 20 & - & 50 & - \\
T5 & - & - & - & - & 100 \\
\hline
\end{tabular}

Legend: BM - Bovine manure; CF - Coconut fiber; CRH - Carbonized rice husk; CCH - Carbonized coffee husk and CS - Commercial substrate based on pine bark, carbonized rice husk and pine bark, vermiculite and NPK.

FLORESTA, Curitiba, PR, v. 51, n. 2, p. 371-380, abril/jun 2021.

Silva, O. M. C. et.al.

ISSN eletrônico 1982-4688

DOI: $10.5380 /$ rf.v51 i2. 69047 
The coffee husks used were donated by rural coffee growers near the production site. Rice husks were acquired from a processing company, located in the Midwest of Minas Gerais. Bovine manure was given by a rural producer near the nursery, being collected in dairy cow pens, with natural pasture as main food, while the commercial substrate and coconut fiber, the latter of coarse texture, were obtained in a store of agricultural inputs.

Fresh coffee husks and rice husks were subjected to the carbonization process outdoors. In an open area in the nursery, $500 \mathrm{~L}$ of the coffee by-product were added, piled around the base of a carbonizer, evenly, and then fire was set on the sides of the carbonizer. With the aid of a shovel and a hoe, the material was turned until complete carbonization and was subsequently spread. In order to avoid any remnants of fire, water was sprinkled with a hose. The same procedure was applied for the carbonization of rice husk.

After this procedure, the proportions of each constituent were determined, and then they were mixed using a concrete mixer until complete homogenization. For better growth of the seedlings, slow-release fertilizer (Osmocote) was added during the mixing process in the proportion $4 \mathrm{~kg} \mathrm{~m}^{-3}$ of substrate.

For physical and chemical characterization, samples of the formulated substrates were sent to the Substrate Laboratory of the Department of Horticulture and Forestry of the Federal University of Rio Grande do Sul (UFRGS). For chemical characterization of the substrates, evaluations of hydrogen potential $(\mathrm{pH})$ determined in water, 1:5 dilution (v/v), and electrical conductivity (EC) obtained in 1:5 solution (v/v) were performed according to the methodology described in Normative Instruction No. 17, of May 21, 2007 (MAPA, 2007). For physical analyses, wet density (WD), dry density (DD), aeration space (AS), total porosity (TP) and water holding capacity (WHC) under $50 \mathrm{~cm}$ suction were determined. For better understanding and reliability of the data, three replicates were performed per sample.

For seedling production, the seeds of the three species were collected in the southern region of Minas Gerais. Tubes of $55 \mathrm{~cm}^{3}$ were used for E. urophylla and tubes of $110 \mathrm{~cm}^{3}$ were used for P. dubium and E. erythropappus. These were placed in trays located in suspended beds, at approximately $80 \mathrm{~cm}$ from the ground. Sowing was performed directly in the tubes, by planting between three and four seeds per container. Subsequently, the seeds were covered with the same substrate used to fill the containers and the trays were covered with $50 \%$ shade net to protection against the action of raindrops and direct radiation. The shade net was removed after the emergence of the seedlings.

At 15 days after germination, thinning was performed, leaving one seedling per container, choosing the one with the highest vigor and the most centralized one. The seedlings were irrigated using a micro-sprinkler system three times a day, with average daily consumption of $15 \mathrm{~mL} /$ tube. At 60 days, the seedlings were alternated to reduce competition for light and increase the spacing between them, contributing to better growth.

During the process of seedling production, cultural practices were carried out, removing weeds and moss from the containers, which could impair their growth. Top-dressing fertilization was applied, using potassium chloride ( $\mathrm{KCl}$ ) and monoammonium phosphate (MAP), in the proportion of $100 \mathrm{~g}$ and $1000 \mathrm{~g}$, respectively, diluted in $100 \mathrm{~L}$ of water, a solution that was applied using a watering can, every two weeks.

In order to avoid the occurrence of fungal diseases, which cause damping-off in E. erythropappus seedlings, treatment was performed with the application of pencycuron (phenyl urea), a protective and specific fungicide for the control of rhizoctonia, with a dose of $3 \mathrm{~mL} \mathrm{~L}^{-1}$, applying the solution on the seedlings with the aid of a manual sprayer.

To evaluate the quality of the seedlings, stem diameter (SD) was measured with a digital caliper (mm) and shoot height $(\mathrm{H})$ was measured with a graduated ruler $(\mathrm{cm})$ at 120 days after sowing. This procedure was done on all seedlings within the plot. Destructive analyses were performed to obtain shoot dry matter (SDM) and root dry matter (RDM). For this procedure, four seedlings per plot were chosen, those that had values closer to the mean for diameter and height. The seedlings chosen had their roots washed in running water to remove the substrate, then the shoots were separated from the root system, and these parts were properly identified, placed in paper bags and taken to an oven, where they remained for a period of 72 hours, at a temperature of $65{ }^{\circ} \mathrm{C}$, and were subsequently weighed on an analytical scale with accuracy of $0.001 \mathrm{~g}$.

After evaluating these characteristics, the total dry matter (TDM) and Dickson quality index (DQI) were calculated, the latter being obtained using the formula of Dickson (1960):

$$
\mathrm{DQI}=\frac{\mathrm{TDM}(\mathrm{g})}{\mathrm{H}(\mathrm{cm}) / \mathrm{SD}(\mathrm{mm})+\mathrm{SDM}(\mathrm{g}) / \mathrm{RDM}(\mathrm{g})}
$$

Where: TDM is total dry matter; $\mathrm{H}$ is shoot height; SD is stem diameter; SDM is shoot dry matter; and RDM is root dry matter.

As qualitative analyses, evaluations of ease to remove the seedlings from the tube (ERT) and root aggregation to the substrate (AGGR) were performed, adapting the methodology described by Wendling et al. (2007). For this procedure, four seedlings were also selected in each plot. For ERT, scores from 1 (maximum

FLORESTA, Curitiba, PR, v. 51, n. 2, p. 371-380, abril/jun 2021 
difficulty) to 10 (maximum ease to remove the seedlings from the container) were assigned after three taps at the top of the tube.

Regarding AGGR, after the seedlings were removed from the tubes, they were dropped from a height of $1 \mathrm{~m}$ from the ground. Scores from 1 (totally crumbled) to 10 (intact) were attributed to the soil lumps around their roots (Figure 1).

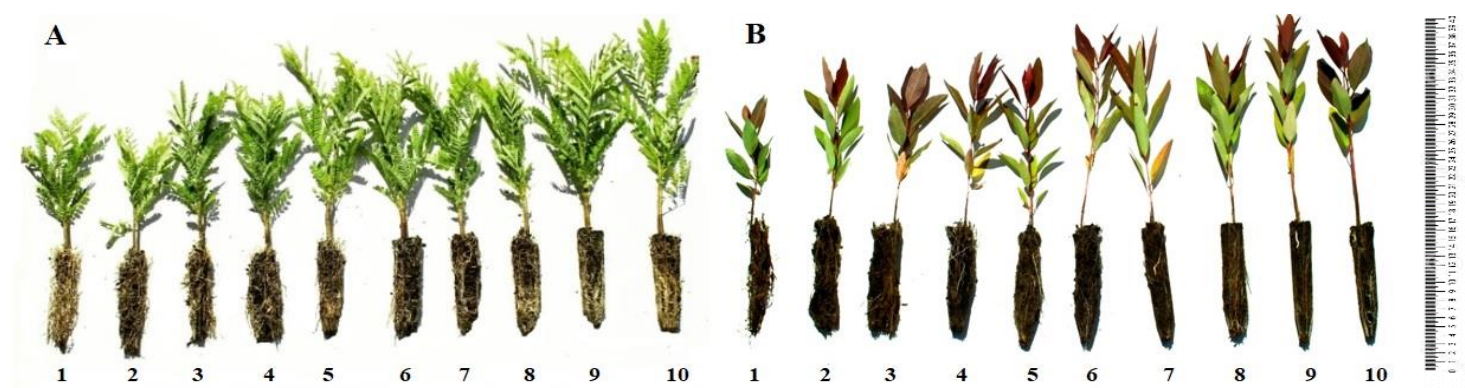

Figure 1. Index of root aggregation to substrate in Peltophorum dubium (A) and Eucalyptus urophylla (B) seedlings at 120 after sowing.

Figura 1. Índices de agregação das raízes ao substrato em mudas de Peltophorum dubium (A) e Eucalyptus urophylla (B), aos 120 após semeadura.

The data obtained were subjected to analysis of variance (ANOVA) and, when significant, Tukey test was applied at 5\% probability of error, using SISVAR software, version 5.6. (FERREIRA, 2014).

To better understand the influence of the different substrate formulations on the quality of the seedlings produced, a multivariate analysis was performed. Through principal component analysis (PCA), it was possible to group the treatments according to their performance. PCA was performed based on the correlation matrix, using the program R Origin Lab Version 8.6 (XIANG et al., 2018).

\section{RESULTS}

Physical and chemical characterization of substrates

The $\mathrm{pH}$ values ranged from 5.53 to 7.59 (Table 2), and only T5 (commercial substrate) had adequate $\mathrm{pH}$ value.

Table 2. Physical and chemical characterization of substrates formulated for the production of Eucalyptus urophylla, Peltophorum dubium and Eremanthus erythropappus seedling.

Tabela 2. Caracterização física e química dos substratos formulados para produção de mudas de Eucalyptus urophylla, Peltophorum dubium e Eremanthus erythropappus.

\begin{tabular}{|c|c|c|c|c|c|c|}
\hline \multirow{2}{*}{ Parameters } & \multirow{2}{*}{ Unit } & \multicolumn{5}{|c|}{ Treatments - proportion in volume of $\mathrm{BM}, \mathrm{CF}, \mathrm{CRH}$ and $\mathrm{CCH}$} \\
\hline & & $30: 20: 50: 0 \%$ & $30: 20: 30: 20 \%$ & $30: 20: 15: 35 \%$ & $30: 20: 0: 50 \%$ & $\begin{array}{c}\text { Commercial } \\
\text { Sub. }\end{array}$ \\
\hline $\mathrm{pH}$ & $\mathrm{H}_{2} \mathrm{O}$ & 6.87 & 7.28 & 7.59 & 7.57 & 5.53 \\
\hline $\mathrm{EC}$ & $\mathrm{mS} \mathrm{cm} \mathrm{cm}^{-1}$ & 1.05 & 0.93 & 1.13 & 1.27 & 0.23 \\
\hline WD & $\mathrm{kg} \mathrm{m}^{-3}$ & 344.76 & 406.82 & 386.19 & 396.14 & 625.47 \\
\hline DD & $\mathrm{kg} \mathrm{m}^{-3}$ & 244.84 & 240.08 & 282.90 & 271.88 & 308.80 \\
\hline $\mathrm{TP}$ & $\%$ & 85.11 & 86.93 & 79.80 & 78.62 & 85.49 \\
\hline AS & $\%$ & 46.21 & 40.96 & 28.69 & 34.64 & 28.17 \\
\hline WHC (50) & $\%$ & 25.87 & 30.76 & 34.07 & 32.21 & 37.90 \\
\hline
\end{tabular}

Legend: $\mathrm{pH}=$ hydrogen potential; $\mathrm{EC}=$ electrical conductivity; $\mathrm{WD}=$ wet density; $\mathrm{DD}=$ dry density; $\mathrm{TP}=$ total porosity; $\mathrm{AS}=$ aeration space; WHC 50 = water holding capacity under suction of $50 \mathrm{~cm}$ of water column.

Regarding electrical conductivity (EC), a small variation was observed between the formulations of treatments $\mathrm{T} 1, \mathrm{~T} 2, \mathrm{~T} 3$ and $\mathrm{T} 4$, ranging from 0.93 to $1.27 \mathrm{mS} \mathrm{cm}^{-1}$. It was noticed that in treatments $\mathrm{T} 3$ and $\mathrm{T} 4$, with higher percentage of coffee husks, the values for conductivity were higher. On the other hand, the control had a lower value, being considered as of low conductivity.

In the evaluation of physical properties, the data were compared according to the classification described by Gonçalves and Poggiani (1996). For wet density, the treatment T1 had the lowest value, $344.6 \mathrm{~kg} \mathrm{~m}^{-3}$. The

FLORESTA, Curitiba, PR, v. 51, n. 2, p. 371-380, abril/jun 2021.

Silva, O. M. C. et.al.

ISSN eletrônico 1982-4688

DOI: 10.5380/rf.v51 i2. 69047 
highest value was obtained in the control, $625.47 \mathrm{~kg} \mathrm{~m}^{-3}$. For wet density, treatments T1, T2, T3 and T4 showed medium values, while the control had high value.

For dry density, the values ranged from 244.84 to $308.80 \mathrm{~kg} \mathrm{~m}^{-3}$. The values of treatments $\mathrm{T} 1$ and $\mathrm{T} 2$, with lower percentages of coffee husks, were lower than those of the other treatments and were considered low. For treatments T3 and T4, when the proportion of this constituent increased, medium values were reached, followed by the control.

Regarding total porosity, it showed low variation among the treatments. The values ranged from 78.62 to $86.93 \%$. The formulated substrates in T1, T2 and T5 had values of $85.11,86.93$ and $85.49 \%$, slightly above the classification indicated by Gonçalves and Poggiani (1996), who consider values for this variable up to $85 \%$ to be adequate. The other treatments had porosity values within the appropriate range.

Although total porosity is an important variable to be evaluated, its interpretation should be performed separately as macroporosity and microporosity. When saturation occurs, macropores are filled by air and their volume is defined as aeration space (AS). On the other hand, micropores are filled with water, and their volume is related to the water holding capacity of the substrate (WHC). In this context, when analyzing macroporosity, treatments T1, T2 and T4 had values of 46.21, 40.96 and 34.64\%, respectively, classified as adequate, while treatments T3 and T5 had values considered medium for this variable. The substrates formulated with bovine manure, coconut fiber, carbonized rice husk and carbonized coffee husk had medium and adequate values for microporosity, while the control showed a value above the indicated.

In the evaluation of water holding capacity, the treatment T5 (control) had the highest values of WHC at $50 \mathrm{~cm}$ in the evaluations, negatively influencing the growth of most of the variables evaluated, possibly due to the excess water caused.

\section{Quantitative and qualitative characteristics of seedlings}

Morphological parameters and qualitative analyses in seedlings of $P$. dubium and E. urophylla are presented in Table 3. There was a statistical difference for most of the characteristics evaluated.

Table 3. Mean values of stem diameter (SD), height (H), shoot dry matter (SDM), root dry matter (RDM), Dickson quality index (DQI), ease to remove the seedlings (ERT) and aggregation index (AGGR) in $P . d u b i u m$ and E. urophylla seedlings at 120 after sowing.

Tabela 3. Valores médios do diâmetro do coleto (SD), altura (H), peso da matéria seca de parte aérea (SDM), peso da matéria seca radicular (RDM), índice de qualidade de Dickson (DQI), facilidade de retirada das mudas dos tubetes (ERT) e índice de agregação (AGGR) em mudas de P. dubium e E. urophylla, aos 120 após semeadura.

\begin{tabular}{|c|c|c|c|c|c|c|c|c|}
\hline \multicolumn{9}{|c|}{ Peltophorum dubium } \\
\hline \multirow{2}{*}{ Treat. } & \multirow{2}{*}{ Proportions $(\%)$} & $\mathrm{SD}$ & $\mathrm{H}$ & SDM & RDM & DQI & ERT & AGGR \\
\hline & & $(\mathrm{mm})$ & $(\mathrm{cm})$ & (g) & (g) & --- & --- & --- \\
\hline $\mathrm{T} 1$ & $30 \mathrm{BM}-20 \mathrm{CF}-50 \mathrm{CRH}-0 \mathrm{CCH}$ & $4.5 \mathrm{a}$ & $17.9 \mathrm{a}$ & $2.69 \mathrm{a}$ & $1.53 \mathrm{ab}$ & $0.74 \mathrm{ab}$ & $3.2 \mathrm{c}$ & $7.0 \mathrm{a}$ \\
\hline $\mathrm{T} 2$ & $30 \mathrm{BM}-20 \mathrm{CF}-30 \mathrm{CRH}-20 \mathrm{CCH}$ & $4.4 \mathrm{a}$ & $17.2 \mathrm{ab}$ & $2.64 \mathrm{a}$ & $1.95 \mathrm{a}$ & $0.89 \mathrm{a}$ & $5.5 \mathrm{bc}$ & $7.6 \mathrm{a}$ \\
\hline $\mathrm{T} 3$ & $30 \mathrm{BM}-20 \mathrm{CF}-15 \mathrm{CRH}-35 \mathrm{CCH}$ & $4.6 \mathrm{a}$ & $18.1 \mathrm{a}$ & $2.69 \mathrm{a}$ & $0.98 \mathrm{~b}$ & $0.55 \mathrm{~b}$ & $6.2 \mathrm{ab}$ & $6.6 \mathrm{a}$ \\
\hline $\mathrm{T} 4$ & $30 \mathrm{BM}-20 \mathrm{CF}-0 \mathrm{CRH}-50 \mathrm{CCH}$ & $3.0 \mathrm{~b}$ & $15.6 \mathrm{ab}$ & $1.68 \mathrm{~b}$ & $1.75 \mathrm{a}$ & $0.56 \mathrm{~b}$ & $8.2 \mathrm{a}$ & $8.1 \mathrm{a}$ \\
\hline $\mathrm{T} 5$ & 100 Commercial substrate & $3.4 \mathrm{~b}$ & $13.8 \mathrm{~b}$ & $2.0 \mathrm{ab}$ & $1.10 \mathrm{~b}$ & $0.54 \mathrm{~b}$ & $8.5 \mathrm{a}$ & $5.8 \mathrm{a}$ \\
\hline \multicolumn{2}{|c|}{$\mathrm{CV} \%$} & 9.9 & 12.1 & 19.9 & 20.8 & 22.5 & 18.9 & 17.7 \\
\hline \multicolumn{9}{|c|}{ Eucalyptus urophylla } \\
\hline \multirow{2}{*}{ Treat. } & \multirow{2}{*}{ Proportions (\%) } & SD & $\mathrm{H}$ & SDM & RDM & DQI & ERT & AGGR \\
\hline & & $(\mathrm{mm})$ & $(\mathrm{cm})$ & $(\mathrm{g})$ & $(\mathrm{g})$ & --- & --- & --- \\
\hline $\mathrm{T} 1$ & $30 \mathrm{BM}-20 \mathrm{CF}-50 \mathrm{CRH}-0 \mathrm{CCH}$ & $2.3 \mathrm{a}$ & $15.4 \mathrm{a}$ & $1.00 \mathrm{a}$ & $0.73 \mathrm{a}$ & $0.22 \mathrm{a}$ & $10.0 \mathrm{a}$ & $9.6 \mathrm{a}$ \\
\hline $\mathrm{T} 2$ & $30 \mathrm{BM}-20 \mathrm{CF}-30 \mathrm{CRH}-20 \mathrm{CCH}$ & $2.1 \mathrm{ab}$ & $14.7 \mathrm{a}$ & $0.76 \mathrm{a}$ & $0.57 \mathrm{a}$ & $0.16 \mathrm{~b}$ & $9.3 \mathrm{~b}$ & $9.1 \mathrm{a}$ \\
\hline $\mathrm{T} 3$ & $30 \mathrm{BM}-20 \mathrm{CF}-15 \mathrm{CRH}-35 \mathrm{CCH}$ & $2.3 \mathrm{a}$ & $15.3 \mathrm{a}$ & $1.03 \mathrm{a}$ & $0.76 \mathrm{a}$ & $0.23 \mathrm{a}$ & $8.4 \mathrm{c}$ & $6.2 \mathrm{c}$ \\
\hline $\mathrm{T} 4$ & $30 \mathrm{BM}-20 \mathrm{CF}-0 \mathrm{CRH}-50 \mathrm{CCH}$ & $2.4 \mathrm{a}$ & $15.9 \mathrm{a}$ & $1.03 \mathrm{a}$ & $0.71 \mathrm{a}$ & $0.22 \mathrm{a}$ & $9.4 \mathrm{ab}$ & $7.0 \mathrm{~b}$ \\
\hline T5 & 100 Commercial substrate & $1.9 \mathrm{~b}$ & $14.7 \mathrm{a}$ & $0.77 \mathrm{a}$ & $0.58 \mathrm{a}$ & $0.15 \mathrm{~b}$ & $9.2 \mathrm{~b}$ & $4.6 \mathrm{~d}$ \\
\hline $\mathrm{CV} \%$ & & 9.0 & 5.0 & 18.6 & 14.9 & 13.5 & $3.1 \mathrm{~b}$ & 4.9 \\
\hline
\end{tabular}

Legend: BM - Bovine manure; CF - Coconut fiber; CRH - Carbonized rice husk; CCH - Carbonized coffee husks. Means followed by the same letter in the column do not differ statistically from each other, by Tukey test at $5 \%$ probability of error.

FLORESTA, Curitiba, PR, v. 51, n. 2, p. 371-380, abril/jun 2021. 
For E. erythropappus, it was not possible to make the evaluation, due to the high mortality of seedlings of this species, in all substrates, during the production process. For P. dubium, the highest means of diameter were obtained in seedlings with the formulations of treatments T1, T2 and T3. For treatments T5 (control) and T4, the lowest means of diameter were found. For E. urophylla, in the diameter evaluation, the lowest values were obtained in seedlings of T5.

When the heights of $P$. dubium seedlings were evaluated, the means ranged from 13.86 to $18.15 \mathrm{~cm}$. The treatment with the highest mean for this variable was T3, statistically differing from T5, which led to shorter seedlings. For the height of E. urophylla seedlings, there were no significant differences between the treatments, with an overall mean of $15.2 \mathrm{~cm}$.

Regarding the data of shoot dry matter (SDM) of $P$. dubium seedlings, the highest values were obtained in treatments T1, T2 and T3. In the evaluation of root dry matter (RDM), the lowest values were observed in seedlings of T3 and T5. For E. urophylla seedlings, there was no significant difference between the treatments in the evaluation of these two variables.

In relation to the Dickson quality index (DQI), it is observed that $P$. dubium seedlings produced with more similar proportions of organic materials were the ones that had significantly higher values. For E. urophylla, seedlings produced in the T2 and T5 formulations had the lowest values of DQI.

In terms of qualitative parameters, Table 3 shows that the presence of $50 \% \mathrm{CRH}$ made it difficult to remove (ERT) P. dubium seedlings from the tubes of $110 \mathrm{~cm}^{3}$. In the evaluation of ERT in E. urophylla seedlings, values close to 10 were obtained, which are considered good, for most treatments, and lower means were obtained only in seedlings of T3.

In the evaluation of root aggregation to the substrate, for $P$. dubium, there were no significant differences between treatments. For AGGR of E. urophylla, the highest values were obtained in T1 and T2. The greatest difference was observed in the control, and this treatment had a value of 4.60.

Figure 2, the result of principal component analysis (PCA), shows the interaction between the components for the two studied species. This differentiated composition among the substrates studied is highlighted in the PCA diagram, in which the first two axes represented $89.4 \%$ of the total variance (PCA1 $=58.2 \%$ and PCA2 $=31.2 \%$ ), for P. dubium, and $90.5 \%$ of the total variance (PCA $1=67.4 \%$ and PCA $2=23.1 \%$ ) for E. urophylla.
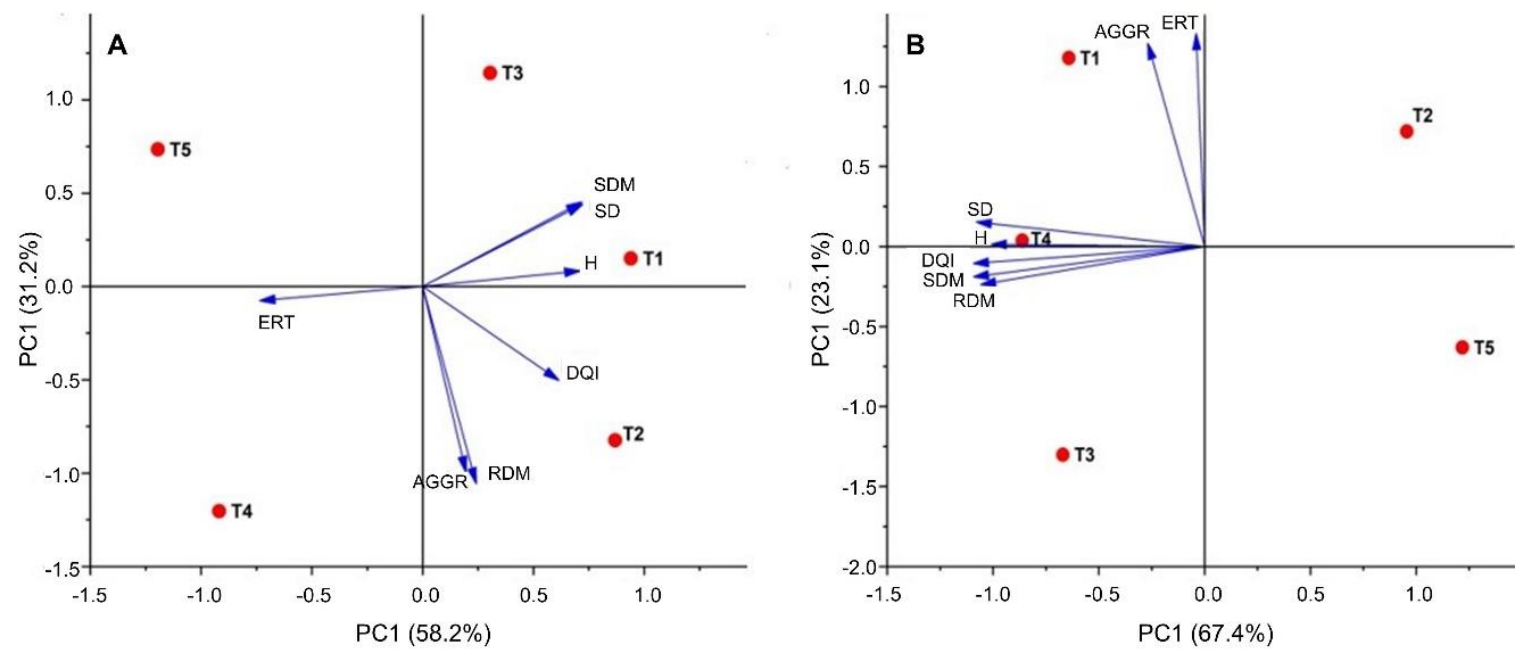

Figure 2. Projection of the two principal components, with details of the performance of the five treatments in relation to the different morphological characteristics SD, H, SDM, RDM, DQI, and qualitative analyses ERT and AGGR on the growth of P. dubium (A) and E. urophylla (B) seedlings.

Figura 2. Projeção dos dois componentes principais, com detalhes do desempenho dos cinco tratamentos em relação às diferentes características morfológicas SD, H, SDM, RDM, DQI, e análises qualitativas ERT e AGGR no crescimento de mudas de P. dubium (A) e E. urophylla (B).

For $P$. dubium seedlings, when analyzing the first principal component, the treatments T1, T2 and T3 are observed on the right side of the vertical line that passes through zero, showing a higher correlation between the variables analyzed, demonstrating that these treatments were better for this species. The treatment $\mathrm{T} 4$ positioned on the left side of the vertical line was correlated only with ERT, being inversely proportional to stem diameter, height and shoot dry matter. The control (T5), also on the left side, showed no correlation with the evaluated characteristics. 
For E. urophylla, when analyzing axis 1, it can be observed that the T4 treatment formulated with $30 \%$ bovine manure, $20 \%$ coconut fiber and $50 \%$ carbonized coffee husks had a high correlation with the variables SD, $\mathrm{H}$, DQI, SDM and RDM, being the most indicated for the production of seedlings of this species. The T1 treatment formulated with $30 \%$ bovine manure, $20 \%$ coconut fiber and $50 \%$ carbonized rice husk showed correlation with ERT and AGGR, and for these two qualitative variables this treatment had the highest values.

It is observed that, in general, the seedlings of $P$. dubium and E. urophylla, produced with commercial substrate, showed significantly lower growth than those produced in the other substrates. When comparing the use of $50 \%$ in volume of carbonized rice husk $(\mathrm{CRH})$ with $50 \%$ of carbonized coffee husk $(\mathrm{CCH})$, it was observed that there were virtually no significant differences. Seedlings with $50 \%$ of $\mathrm{CCH}$ were easier to be removed from the tubes, compared to those produced with $\mathrm{CRH}$ for $P$. dubium, while for E. urophylla, the behavior of this operation did not differ statically from each other, considering the proportions of the formulations mentioned above.

\section{DISCUSSION}

In relation to the mortality of E. erythropappus seedlings, in the case of the commercial substrate, this occurred possibly due to the physical characteristics of the substrate, mainly visualized by WD and WHC at 50 $\mathrm{cm}$. For the other substrates, the high mortality may have occurred due to the proportion of manure $(30 \%)$ contained in the treatments, because as already elucidated by Melo et al. (2014), who evaluated the initial growth of this species under different substrate formulations and found that the use of bovine manure in the substrate was detrimental to the survival and growth of seedlings.

Regarding the chemical analyses of the substrates, the ideal $\mathrm{pH}$ range for most forest crops is within the range from 5.5 to 6.5 (GONÇALVES and POGGIANI, 1996; FERMINO, 2014). When the pH is outside this range, the tree seedlings cannot absorb nutrients efficiently; as a consequence, this compromises the growth of their roots. These $\mathrm{pH}$ values higher than 6.5 in the other four treatments differing from the control were probably due to the use of carbonized material, as the carbonization process produces ash, which usually increases the $\mathrm{pH}$ of the material.

Electrical conductivity above $3.5 \mathrm{mS} \mathrm{cm}^{-1}$ is considered excessive for most cultivated plants. In general, for forest species, the EC should be between 1.5 and $3.0 \mathrm{mS} \mathrm{cm}$. The high values of electrical conductivity observed in the formulations containing a higher percentage of coffee husks may be related to a possible increase in the concentration of salts in this substrate, due to the carbonization process (Silva et al., 2020). High values of electrical conductivity can damage plant roots and root hair, which can interfere with the absorption of water and nutrients and, consequently, impair seedling growth.

In the analysis of physical properties, for Gonçalves and Poggiani, (1996), in the evaluation of porosity, values below $250 \mathrm{~kg} \mathrm{~m}^{-3}$ are considered low, values between 250 and $500 \mathrm{~kg} \mathrm{~m}^{-3}$ are considered medium and values above $500 \mathrm{~kg} \mathrm{~m}^{-3}$ are considered high. In general, formulations that generate denser substrates have less space between particles, which compromises gas exchange and water circulation, hindering the root growth of seedlings.

One of the ways to increase the macroporosity of a substrate is the complementation of the constituents with lighter material (GONÇALVES and POGGIANI, 1996). Materials containing husks in their composition, such as rice and coffee husks used in this study, can usually be applied. The results obtained in this study, for macro and microporosity, corroborate those of Gonçalves and Poggiani (1996), who state that materials with low density, such as carbonized materials, increase the macroporosity of mixtures and reduce the water holding capacity of the substrate. However, attention should be paid because, according to Guerrini and Trigueiro (2004), high proportions of materials such as husks become unviable, due to the high consumption of water for irrigation.

As physical criteria, the water holding capacity should be considered as of paramount importance for the evaluation of substrate quality. According to Wendling et al. (2007), substrates that have low WHC require higher irrigation depths, whereas in substrates with greater microporosity there should be greater control over irrigation to avoid soaking and reduction in root aeration.

Regarding biometric variables, stem diameter is one of the most observed characteristics when evaluating the quality parameters of a seedling, as it may indicate the survival capacity and also the growth of seedlings in the field (GROSSNICKLE et al., 2018). For stem diameter, Davide et al. (2015) suggest that the value of $3 \mathrm{~mm}$ in diameter can be considered as a minimum standard for native forest species in the expedition phase. In this context, the seedlings of all treatments of the species $P$. dubium had higher values than those stipulated by these authors. For seedlings of exotic species, such as E. urophylla, the value should be equal to or greater than $2 \mathrm{~mm}$ (WENDLING et al., 2007), which did not occur only for the seedlings of the control treatment. It can be affirmed that the alternative constituents were essential for the growth in diameter of the two species.

Similar values in stem diameter (2.14 to $3.21 \mathrm{~mm}$, after 110 days of sowing) were obtained by Melo et al. (2014), for Eucalyptus grandis seedlings, when evaluating different substrate formulations, containing aged corral manure, carbonized rice husk and coconut fiber. In contrast, Kratz et al. (2013b), evaluating the initial

FLORESTA, Curitiba, PR, v. 51, n. 2, p. 371-380, abril/jun 2021.

Silva, O. M. C. et.al.

ISSN eletrônico 1982-4688

DOI: $10.5380 /$ rf.v51 i2. 69047 
growth of Eucalyptus benthamii seedlings in substrates formulated with coconut fiber, carbonized rice husk, sewage sludge and semi-decomposed pine bark, in different formulations, observed average stem diameter of 1.70 $\mathrm{mm}$, which is below that found in this study.

Although $P$. dubium seedlings did not reach $20 \mathrm{~cm}$ in height until 120 days, they had characteristics of rustic seedlings, with adequate diameter and well-developed shoots and roots, being indicated for planting in the field. Seedling height is a criterion widely used in the evaluation of seedling quality, being widely adopted mainly because it is easy to measure and not a destructive method. However, this characteristic should be evaluated in conjunction with other variables to better understand the results (DAVIDE et al., 2015).

The positive results found for P. dubium in treatments T1, T2 and T3 may be related to the constituents bovine manure, carbonized rice husk and carbonized coffee husk, which are considered organic materials and contributed to improving the physical and chemical conditions of the substrates (GUERRINI and TRIGUEIRO, 2004). Another factor that may have contributed to the results of these treatments was the use of coconut fiber together with coffee husk and/or rice husk, which are considered light and porous materials, contributing to the better growth in height of the seedlings (GONÇALVES and POGGIANI, 1996). However, when there was a high percentage of coffee husks, as in T4, $P$. dubium seedlings did not grow satisfactorily. On the other hand, this treatment had good values for E. urophylla seedlings, pointing to different behavior between the two species.

Caldeira et al. (2013) evaluated the influence of alternative substrates on the production of Chamaecrista desvauxi seedlings and found that the constituents of carbonized rice husk and coffee husk were effective for the growth in height of the seedlings of this species. Similar data were obtained in the present study, in which the seedlings had higher values for this variable, when compared to those of the control treatment.

One way to present the results in a summarized form, in a single value, is through the Dickson quality index (DQI), which is considered a good indicator for assessing the seedling quality, as it aggregates the other morphological parameters in a single evaluation, and the higher its value, the greater the capacity of the seedling to survive in the field (CALDEIRA et al., 2014). This parameter is widely used in the evaluations, because it considers the sturdiness and balance between the characteristics of seedling quality evaluation.

The literature shows that DQI varies according to the species, type of constituent used in the formulations of substrates, form of management of seedlings in the nursery, among others (TRAZZI et al., 2012; GOMES et $a l ., 2013)$. Despite variations, this index can be used in the comparison of lots of seedlings of the same species.

In the evaluation of qualitative parameters, Kratz et al. (2016) analyzed the ERT of Eucalyptus camaldulensis seedlings in substrates based on carbonized rice husk and found that all treatments evaluated led to values close to 8 . The data found in the present study, in E. urophylla seedlings, were higher than those obtained by Kratz et al. (2016), while for $P$. dubium seedlings the results were lower.

According to methodology described by Wendling et al. (2007), the lower the value for this index, the greater the difficulty of removing the seedlings from the tubes, and it may also indicate that there is a greater amount of roots in the treatments T1 and T2, which may have interfered in this procedure. On the other hand, the fact that a greater amount of roots hinders the ERT may indicate that in these treatments the seedlings had greater root formation (FRAGOSO et al., 2016), being considered essential for better growth in the field.

Evaluating the removal of seedlings from the tubes is important, as it is related to the quality of the lump formed and considers whether the removal of seedlings from the tubes is a costly activity or not (WENDLING $e t$ al., 2007). The easier this operation, the lower the cost for preparing the seedlings for planting. However, according to Guerrini and Trigueiro (2004), ERT may be related to poor rooting, thus pointing to an easy operation, but consequently being a negative characteristic of low amount of root biomass, being harmful to the growth of plants in the field (FRAGOSO et al., 2016).

Wendling et al. (2007), when evaluating substrate aggregation in the cultivation of Ilex paraguariensis seedlings in organic substrates, composed of pine bark, bovine manure, sawdust, semi-decomposed sawdust, yerba mate chopped stems, subsoil earth and earthworm humus, obtained values between 6 and 9 for aggregation of roots to the substrate. For this study, the AGGR value considered low observed in the control may have been caused by the excess water, which led to physical impediment.

Principal component analysis was considered appropriate, because it efficiently demonstrated in graphs the behavior of the different treatments in relation to the variables evaluated, being an important tool to be used for better accuracy of the data (XIANG et al., 2018).

In the present study, the values obtained for seedlings produced in the proportions between carbonized rice husk and carbonized coffee husk were higher than those of the seedlings in the control treatment. Thus, it can be inferred that the alternative constituents had a significant role in the increase of the variables evaluated, corroborating data obtained by Kratz and Wendling (2013) and Silva et al. (2020), who evaluated similar constituents.

FLORESTA, Curitiba, PR, v. 51, n. 2, p. 371-380, abril/jun 2021. 


\section{CONCLUSIONS}

- Carbonized coffee husks were viable for the production of $P$. dubium and E. urophylla seedlings. Formulations with 20 and $35 \%$ coffee husks, combined with rice husk, coconut fiber and bovine manure were the most suitable for the production of $P$. dubium seedlings, partially replacing the need for using carbonized rice husk.

- For the production of E. urophylla seedlings, the formulation with $50 \%$ carbonized coffee husks, complemented with $30 \%$ manure and $20 \%$ coconut fiber (5:3:2) is recommended, totally replacing the need for using carbonized rice husk in the production of E. urophylla seedlings.

- For E. erythropappus, none of the formulations had satisfactory data, and the use of these constituents in these proportions is not indicated for the production of seedlings of this species.

\section{ACKNOWLEDGMENTS}

The authors thank Cemig, UFLA and the Coordination for the Improvement of Higher Education Personnel (CAPES).

\section{REFERENCES}

ALONSO, J. M.; ABREU, A. H. M.; MELO, L. A.; LELES, P. S. S.; CABREIRA, G. V. Biosolids as substrate for the production of Ceiba speciosa seedlings. Cerne, v. 24, p. 420-429, 2018.

CALDEIRA, M. V. W.; GONÇALVES, E. O.; TRAZZI, P. A.; DELARMELINA, W. M.; ROCHA, R. L. F. Crescimento de mudas de Eucalyptus grandis utilizando lodo de esgoto, fibra de coco e palha de café in natura. Floresta, Curitiba, v. 44, n. 2, p. 195-206, 2014.

CALDEIRA, M.V.W.; DELARMELINA, W. M.; FARIA, J. C. T.; JUVANOL. R.S. Substratos alternativos na produção de mudas de Chamaecrista desvauxii. Revista Árvore, v. 37, n. 1, p. 31-39, 2013.

Companhia Nacional de Abastecimento (CONAB). A cultura do arroz / organizador Aroldo Antonio de Oliveira Neto. - Brasília, 2015. 180 p.

DAVIDE, A. C.; BOTELHO, S. A. Fatores que afetam a qualidade de mudas destinadas aos projetos de restauração de ecossistemas florestais. In: Davide, A. C.; Botelho, S. A. (Ed.). Fundamentos e métodos de restauração de ecossistemas florestais: 25 anos de experiência em matas ciliares. Lavras: Ed. UFLA, p. 181-274, 2015.

DELARMELINA, W. M.; CALDEIRA, M. V. W.; FARIA, J. C. T.; GONÇALVES, E. O.; ROCHA R. L. F. Diferentes substratos para a produção de mudas de Sesbania virgata. Floresta e Ambiente, v. 21, n. 2, p. 224233, 2014.

DICKSON, A.; LEAF, A.L.; HOSNER, J.F. Quality appraisal of white spruce and white pine seedling stock in nurseries. Forest Chronicle, v. 36, p. 10-13, 1960.

DORNELleS, P.; SILVA, F. G.; MOTA, C. S.; SANTANA, J. G. Production and quality of Anacardium othonianum Rizz. seedling grown in different substrates. Revista Brasileira de Fruticultura, v. 36, n. 2, p. 479486, 2014.

FERMINO, M. H. Substratos: composição, caracterização e métodos de análise. Guaíba: Agrolivros, p. 111, 2014.

FERREIRA, D. F. SISVAR: A guide for its bootstrap procedures in multiple comparisons. Ciência e Agrotecnologia, Lavras, v. 38, n. 2, p.1 09-112, 2014.

FRAGOSO, R. O.; STUEPP, C. A.; APARECIDO CARPANEZZI, A. A.; WENDLING, I.; ZUFFELLATORIBAS, K. C.; KOEHLER, H. S. Substratos renováveis na produção de mudas de Ficus enormis proveniente de jardim clonal. Pesquisa Florestal Brasileira, Brasília v. 36, p. 537, 2016.

GOMES, D. R.; CALDEIRA, M. V. W.; DELARMELINA, W. M.; GONÇALVES, E. O.; TRAZZI, P. A. Lodo de esgoto como substrato para a produção de mudas de Tectona grandis L. Cerne, Lavras, v. 19, n. 1, p. 123-131, 2013.

GONÇALVES, L. M.; POGGIANI, F. Substratos para produção de mudas florestais. In: Congresso Latino Americano de Ciência do Solo, 13. Águas de Lindóia, 1996. Resumos. Piracicaba, Sociedade Latino Americana de Ciência doSolo, CD-ROM, 1996.

FLORESTA, Curitiba, PR, v. 51, n. 2, p. 371-380, abril/jun 2021. 
GROSSNICKLE, S. C.; MACDONALD, J. E. Seedling quality: history, application, and plant attributes. Forests, v. 9. p. 283, 2018.

GUERRINI, I. A.; TRIGUEIRO, R. M. Atributos físicos e químicos de substratos compostos por biossólidos e casca de arroz carbonizada. Revista Brasileira de Ciência do Solo, v. 28, n. 6, p. 1069-1076, 2004.

KRATZ, D.; WENDLING, I. Crescimento de mudas de Eucalyptus camaldulensis em substratos à base de casca de arroz carbonizada. Revista Ceres, Viçosa, v. 63, p. 348-354, 2016.

KRATZ, D.; WENDLING, I. Produção de mudas de Eucalyptus dunnii em substratos renováveis. Floresta, Curitiba, v. 43, n. 1, p. 125-136, 2013.

KRATZ, D.; WENDLING, I.; NOGUEIRA, A. C.; SOUZA, P. V. D. Propriedades físicas e químicas de substratos renováveis. Revista Árvore, Viçosa, v. 37, n. 6, p. 1103-1113, 2013 a.

KRATZ, D.; WENDLING, I.; NOGUEIRA, A. C.; SOUZA, P. V. D. Substratos renováveis na produção de mudas de Eucalyptus benthamii. Ciência Florestal, Santa Maria, v. 23, n. 4, p. 607-621, $2013 \mathrm{~b}$.

MELO, L. A.; PEREIRA, G. A.; MOREIRA, E. J. C.; DAVIDE, A. C.; SILVA, E. V.; TEIXEIRA, L. A. F. Crescimento de mudas de Eucalyptus grandis e Eremanthus erythropappus sob diferentes formulações de substrato. Floresta e Ambiente, v. 21, n. 2, p. 234-242, 2014.

Ministério da Agricultura, Pecuária e Abastecimento (MAPA). Instrução Normativa SDA no 17. Diário Oficial da União - Seção 1, n ${ }^{\circ}$ 99, 24 de maio de 2007. Métodos analíticos oficiais para análise de substratos para plantas e condicionadores de solo. Brasília, 2007. Available at: < http://www.agricultura.gov.br/assuntos/insumosagropecuarios/insumos-agricolas/fertilizantes/legislacao/in-17-de-21-05-2007-aprova-metodo-substrato.pdf>. Accessed on May 22, 2019.

SILVA, O. M. C.; HERNANDEZ, M. M.; ARAUJO, G. C. R.; CUNHA, F. L.; EVANGELISTA, D. V. P.; LELES, P. S. S.; MELO, L. A. Potencial uso da casca de café como constituinte de substrato para produção de mudas de espécies florestais. Ciencia Florestal, v. 30, n. 4, p. 1161-1175, 2020.

TRAZZI, P. A.; CALDEIRA, M. V. W.; COLOMBI, R.; PERONI, L.; GODINHO, T. O. Estercos de origem animal em substratos para a produção de mudas florestais: atributos físicos e químicos. Scientia Forestalis, Piracicaba, v. 40, n. 96, p. 455-462, 2012.

WENDLING, I.; GUATALA, D; DEDECEK, R. Características físicas e químicas de substratos para produção de mudas de Ilex paraguariensis St. Hil. Revista Árvore, v. 31, p. 209-220, 2007.

XIANGI LI.; YMING F.; SHARON TING.; JIANG.; YUNFA LIU. Correlating emulsion properties to micro encapsulation efficacy and nutrients retention in mixed proteins system. Food Research International, n, 115, p. 44-53, 2018. 